\title{
The Role of Jordanian Agricultural Policies in Climate Change Responding Affecting Agricultural Production
}

\author{
Radi A. Tarawneh ${ }^{1}$ \\ ${ }^{1}$ Collage of Agriculture, Jerash University, Jerash, Jordan \\ Correspondence: Radi A. Tarawneh, Collage of Agriculture, Jerash University, Jerash, Jordan. Tel: \\ 962-799-059-944. E-mail: r.tarawneh@jpu.edu.jo
}

Received: March 8, 2021

Accepted: April 25, $2021 \quad$ Online Published: May 15, 2021

doi:10.5539/jas.v13n6p90

URL: https://doi.org/10.5539/jas.v13n6p90

The research is financed by Jerash University.

\begin{abstract}
A study was conducted in Jordan to evaluate the role of Jordanian agricultural policies on agricultural production under the effect of climate change. A scientific questionnaire was distributed to 100 samples of Jordanian citizens who had direct contact with the effect of agricultural policies and they can touch the effect of climate change and agricultural policies on the agricultural production, data selected from farmers, agricultural rural communities, agricultural sector decision makers, and agricultural researchers were selected randomly from different areas in Jordan. The results show that Jordanian are aware of the climate change effect on the agricultural sector and agricultural production, they believe that the most effective ways to face the negative effect of climate change on agricultural production by implementing agricultural regulations and policies which try to develop the Jordan agricultural sector under the effect of climate change. On other hand, results show a significant effect of agricultural policies to adapt and face the climatic changes in Jordan.
\end{abstract}

Keywords: climate change, agricultural policies, production, Jordan

\section{Introduction}

Climate change is seen as the most important change that will affect the agricultural sector in developing countries, as the vulnerability of this sector is high and adaptation measures are restricted by the limited resources of these countries. In Jordan, agriculture is one of the most sensitive sectors to climate change-induced impacts. Due to urban expansion in the high rainfall zones, rain-fed agriculture had expanded towards the marginal lands of arid and semiarid areas that receive less than $200 \mathrm{~mm}$ of annual rainfall. For many years, rain-fed agriculture in these areas suffers from droughts and accelerated soil degradation, and overgrazing of natural vegetation (UNFCCC, 2009).

According to the fact that Agriculture is highly sensitive to climate variability and weather extremes - such as droughts, floods, and severe storms - the forces that shape our climate are also critical to farm productivity. Human activity has already changed atmospheric characteristics such as temperature, rainfall, levels of carbon dioxide $\left(\mathrm{CO}_{2}\right)$, and ground-level ozone. The scientific community expects such trends to continue. While food production may benefit from a warmer climate, the increased potential for droughts, floods, and heatwaves will pose challenges for farmers. Additionally, the enduring changes in climate, water supply, and soil moisture could make it less feasible to continue crop production in certain regions. The Intergovernmental Panel on Climate Change (IPCC) (2007) concluded that the increased frequency of heat stress, droughts, and floods negatively affect crop yields and livestock beyond the impacts of mean climate change, creating the possibility for surprises, with larger impacts, and occurring earlier, than predicted using changes in mean variables alone. This is especially the case for subsistence sectors at low latitudes. Climate variability and change also modify the risks of fires, pests, and pathogen outbreaks, negatively affecting food, fiber, and forestry. In the Jordan case, according to the population growth and the need to increase food production by using modern techniques in agriculture, the impact of climate change was affected the water availability in Jordan.

Jordan is experiencing harsh water shortages in different parts of the country due to high fluctuations in annual precipitation; the only source of water. Also, heat waves are becoming more frequent in the region. Precipitation 
decrement and summer heatwaves are being blamed on global warming (Moshrik et al., 2009). Jordan agricultural policies were emerging to reduce the effect of climate change on the Agricultural sector by applying many regulations and issue strategies that could reduce the effect of climate change. Jordan Department of Statistics data show that; the agricultural areas were increased instead of the reduction of water quantity for irrigation in Jordan, this leads us to ask: What are the reasons for increased agricultural areas? What is the effect of climate change on the agricultural sector in Jordan? What is the role of agricultural policies to increase the agricultural areas and to reduce the effect of climate change?

The Ministry of Agriculture in Jordan was aware of the climate change effect, looking forward to sharing the world to reduce the effect of climate change and global warming by initiating different regulations. The development of the agriculture portfolio to mitigate the impact of drought on the plant and reduce the use of machinery, fuel, pesticides, and fertilizers, increasing the forest area and everlasting the forests including the biodiversity encouragement was one of the challenges that the Ministry of Agriculture tries to improve, to play a great role side by side with other countries to eliminate the side effect of climate change and global warming. The Ministry of Agriculture has taken considerable measures needed to gradually reduce the use of Methyl Bromide which had a negative effect on ozone layer and other effects on climate. This strategy is an embodiment of continuous efforts made to find out Methyl Bromide alternatives, suitable for Jordan which signed the Vienna Protocol in 1989 where many countries were involved and obliged to stop using ozone layer depletion materials. The National Committee of Montreal Fund, during Beijing conference in 1999, agreed on financing an agricultural project in Jordan, regarding MB alternatives projects' results, the committee approved on financing the national strategy of Methyl Bromide phase-out according to Vienna agreement schedule, in 2020, Jordan was clear from using of Methyl Bromide. Ministry of Agriculture was aware to produce healthy safe food and protect of agricultural soil and environment, Jordan become as a member of the Mediterranean Organic Agriculture Network (MOAN) (2001); an organic farming society in Jordan was initiated in the Ministry of Agriculture, develop of pesticide residue laboratories testing all the harmful pesticide residues in agricultural products that affect the quality of agricultural products (also pesticides had a negative effects on agricultural environment) which produced in Jordan or imported abroad, on other hand, the ministry develop instructions for registration of bio-pesticides regulation number $z / 6,2016$, formed by a committee of specialists in the Ministry of Agriculture and Jordanian universities, which will lead to a relaxation of registration of these pesticide and started using biological control to several Agricultural pests instead of using chemical pesticide which are harmful to climate and quality of agricultural products, besides, Ministry of Agriculture policies also try to enhance farmers to use of water saving techniques and spread of new technology to increase agricultural production per unit area.

\section{Literature Review}

\subsection{Climatic Factors Affected Agricultural Productivity}

Climate change scenarios indicate that Jordan and the Middle East could suffer from reduced agricultural productivity and water availability among other negative impacts (World Bank, adaptation to a Changing Climate in the Arab Countries, 2012)

Jordan has many different climatic regions; at least there are three different climatic regions, as sub-tropical, Mediterranean, and Badia and desert. Only about 5\% of Jordan's landmass is considered arable, while the country is among the world's most four water-deficient countries. Agriculture is one of the most sensitive sectors to climate change-induced impacts. The increased temperatures and lower precipitation resulting from climate change would adversely affect crops and water availability, critically influencing the patterns of future agricultural production in Jordan. The main expected impacts of these scenarios are, a decrease in available soil moisture for crops in the rainfed areas, increased crop water requirement, increased crop/weed competition, more frequent drought, decreased streamflow, changes in rainfall intensity with more possible floods, shortened growing season and reduction in yield of rainfed and irrigated crops (Ministry of Environment, The National Climate Change Policy of the Hashemite Kingdom of Jordan 2013-2020).

Several factors are directly connected to climate change and agricultural productivity in Jordan; the category of GHG emissions includes changes in forest and other woody biomass stock, forest and grassland conversion, abandonment of managed lands, carbon dioxide emissions, and removals from the soil. The net emissions were about $4 \%$ of national emissions in 2000 . The agricultural sector contributes little to the overall GHG emissions (about $1 \%$ in 2000) and at the same time provides little opportunities for mitigation (2nd National Communication, 2009). Additionally; increasing atmospheric $\mathrm{CO}_{2}$ levels, driven by emissions from human activities, can act as a fertilizer and enhance the growth of some crops such as wheat. $\mathrm{CO}_{2}$ can be one of many limiting factors that, when increased, can enhance crop growth. Other limiting factors include water and nutrient 
availability. While it is expected that $\mathrm{CO}_{2}$ fertilization will have a positive impact on some crops, other aspects of climate change (e.g., temperature and precipitation changes) may temper any beneficial $\mathrm{CO}_{2}$ fertilization effect, the IPCC (2007) reported that; higher levels of ground-level ozone limit the growth of crops since ozone levels in the lower atmosphere are shaped by both emissions and temperature, climate change will most likely increase ozone concentrations. Such changes may offset any beneficial yield effects that result from elevated $\mathrm{CO}_{2}$ levels, on the other hand, the changes in the frequency and severity of heatwaves, drought, floods, and hurricanes, remain a key uncertainty in future climate change. Such changes are anticipated by global climate models, but regional changes and the potential effects on agriculture are more difficult to forecast (IPCC, 2007).

\subsection{Jordan Strategies and Policiesto Adapt to Climate Change}

Climate change is set to worsen the difficult environmental, political, economic, and social situation in Jordan; the Government has adopted general and sector-specific climate policies, and actively engaged diverse actors on these issues at domestic, regional, and international levels. However, while it has achieved some successes, important gaps and shortcomings in policy and action remain, due to a mix of legislative, regulatory, institutional, political, and economic factors.

Jordan government's overarching 2025 National Vision and Strategy and National Green Growth Plan, the National Climate Change Policy, and Sector Strategic Guidance Framework have now been extended to 2030; Jordan Government has put the emphasis on adaptation rather than mitigation, intending to achieve both socio-economic development and environmental resilience. The priority sectors for government are water, agriculture, energy, land use, and desertification. On the water, the key policies are "Water for Life: Jordan's Water Strategy (2008-2022)", the National Water Strategy for 2016-2025, and the Climate Change Policy for a Resilient Water Sector. On energy, the key policies are the Master Strategy in the Energy Sector (2015-2025), and the policies based on the 2012 Renewable Energy and Energy Efficiency Law, on the agricultural sector, the key policies are National Strategy for agricultural development 2016-2025.

Internationally, Jordan remains highly dependent on regional and global exchanges. Regionally, it has sought to cooperate with Israel and Syria on water, but both countries have violated agreements and overused water to the detriment of Jordan (Combaz, 2019).

In 2015, the government launched Jordan's 2025 National Vision and Strategy (NVS). This is the reference for all development pathways in the country, "and sets a holistic economic and social framework based on equal opportunities for all". It contains over 400 policies, including ones on environment and climate (Bany Yasin, 2018; EcoPeace, 2019), alongside the agricultural sector policies such as the National Strategy for Agricultural Development 2016-2025 and the development of the Agricultural Low No. 13 of 2015.

\subsection{Water Availability for Irrigation Purposes}

The high rainfall areas suffered from urbanization and land fragmentation which resulted in permanent loss of these lands. Much of the country's land can be classified as unsuitable for agriculture and rainfall varied greatly from one year to another, Jordan Department of Statistics (DOS) (2021) illustrated that the rainfall volume for the season 2017-2018 was 7146 million cubic meters which is below the long term average (during the years 1937-2018) which was 8193 million cubic meters (DOS, 2021), between 6\% and 7\% of Jordan's territory was arable, a figure that was being revised slowly upward as dry-land farming techniques became more sophisticated. According to arable, rain-fed land was exploited extensively, future growth of agricultural production depended on increased irrigation. Only about $20 \%$ of Jordan's geographic area received more than 200 millimetres of rainfall/year, the minimum required for rain-fed agriculture (UNFCCC, 2009).

In 2016, Jordan Ministry of Water and Irrigation issue a water redistribution policies document, show the policies related to water availability and the vision of future water situation in Jordan, policy document shows that total water use for irrigation purposes was 729 million cubic meters from different water resources which consist of $61 \%$ of total water available in Jordan, on the other hand, the Water and Irrigation Ministry mentioned that the irrigation water quantities were reduced from $660 \mathrm{~m}^{3} / \mathrm{m}$ to $530 \mathrm{~m}^{3} / \mathrm{m}$ in 2014 , the amount of water reduced shifted to drinking purposes.

\subsection{Heat Waves and Temperature Affected Agricultural Production}

The increasing temperature average is one of the critical issues that affect agricultural productivity by lengthening the growing season with a relatively cool spring and fall, adversely affect crops in regions where summer heat already limits production, increase soil evaporation rates and increase the chances of severe droughts, also changes in rainfall can affect soil erosion rates and soil moisture, both of which are important for crop yields. The IPCC predicts that precipitation will increase in high latitudes, and decrease in most subtropical 
land regions - some by as much as about $20 \%$-while regional precipitation will vary the number of extreme precipitation events is predicted to increase (IPCC, 2007). Jordan temperature affected as to all countries by Global warming. If climate change continues at its current pace, the Kingdom is expected to witness a $1-2{ }^{\circ} \mathrm{C}$ increase in temperatures by 2030-2050, resulting in diminished aquifers and oases, reduced green cover, and the transformation of semi-arid lands, some $80 \%$ of the country's total area, into arid deserts (Namrouqa, 2009). The mean annual maximum temperature produces a great spatial variability in Jordan depending on the topographic nature of the country. Winter maximum temperature has a characteristic increasing gradient from $9-13{ }^{\circ} \mathrm{C}$ in northern and southern heights to $14-16{ }^{\circ} \mathrm{C}$ in the desert area to $19-22{ }^{\circ} \mathrm{C}$ in Jordan Valley. The maximum mean temperature is inversely proportional to the elevation; it varies from 20 to $23{ }^{\circ} \mathrm{C}$ in mountainous areas and increases to $26^{\circ} \mathrm{C}$ in the desert region. In Jordan Valley, the annual maximum temperature increases southward and varies from 29 to $31^{\circ} \mathrm{C}$. In summer, high averages of maximum temperature prevail and reach $38-39{ }^{\circ} \mathrm{C}$ in Jordan Valley, $35-37{ }^{\circ} \mathrm{C}$ in a desert region and decrease to $26-29{ }^{\circ} \mathrm{C}$ in the mountainous region, causing a large spatial variation from west to east and south. The minimum temperature is an important climatic element due to its deterministic relation to agricultural activities. Mean annual minimum temperature differs from mean annual maximum temperature by having the lowest values, not in the northern heights, but southern heights and some of the arid areas. Shoubak has the lowest mean annual minimum temperature $\left(5.6{ }^{\circ} \mathrm{C}\right)$, which is followed by the QAIA (7.8 o C), Mafraq $\left(9{ }^{\circ} \mathrm{C}\right)$, and then the northern heights and the desert area. The warmest region in the country is Jordan Valley where the mean annual minimum temperature ranges between $15.7^{\circ} \mathrm{C}$ in the north and $19.5^{\circ} \mathrm{C}$ in the southern part of the Valley (Freiwan \& Kadioglu, 2008). During summer the Jordan Valley is very hot, and the mean daily maximum is $39{ }^{\circ} \mathrm{C}$. The highest observed temperature is $51.2{ }^{\circ} \mathrm{C}$ near the Dead Sea. During winter the mean minimum temperature is about $9^{\circ} \mathrm{C}$, the temperature is pleasant and frost is rare. In the mountainous region, it is rather cold during winter, and the mean daily minimum temperature is about $4{ }^{\circ} \mathrm{C}$. The lowest recorded temperature at Amman Airport is $-7.5^{\circ} \mathrm{C}$, and at Shoubak is $-12{ }^{\circ} \mathrm{C}$. The annual number of days with air frost is $10-15$ days. During summer it is pleasant, and the mean daily maximum temperature is about $26{ }^{\circ} \mathrm{C}$ to $30{ }^{\circ} \mathrm{C}$. Amman, the capital of Jordan, is a mountainous city that enjoys four seasons of excellent weather when compared to other places in the region. Summer temperatures range from $28^{\circ} \mathrm{C}$ to $35^{\circ} \mathrm{C}$, but with very low humidity and frequent freezes. Spring and fall temperatures are extremely pleasant and mild. The winter sees nighttime temperatures frequently near $0{ }^{\circ} \mathrm{C}$, and snow is known in Amman. It usually snows a couple of times per year.

\subsection{Agricultural Area Development in Jordan}

According to the numbers of the Jordan Department of Statistics (DOS) (2021), shows a dramatic increase in agricultural areas from 2011 to 2019 despite the reduction of irrigation water quantities from the Ministry of Water and Irrigation (Table 1). The numbers of agricultural production in Jordan recorded by the Department of Statistics (DOS) (2021), Table 2 shows a stable agricultural production for the years from 2011 to 2019 with a slight increase during the years 2015 and 2016.

Table 1. Agricultural areas development in Jordan from 2011 to 2019 per thousand donums

\begin{tabular}{llllllllll}
\hline Item & 2011 & 2012 & 2013 & 2014 & 2015 & 2016 & 2017 & 2018 & 2019 \\
\hline Field Crops & 1129 & 1155 & 1278 & 1385.5 & 1314 & 1354.9 & 736.7 & 963.7 & 1071.7 \\
Fruit Trees & 850 & 859 & 836 & 845.3 & 864.2 & 867 & 780.7 & 784.2 & 796.6 \\
Vegetables & 429 & 423 & 495.4 & 508.7 & 487.7 & 505.5 & 376.9 & 374.4 & 334.1 \\
Irrigated areas & 964.5 & 931 & 1034.4 & 1050.5 & 1034.8 & 1065.3 & 1190.7 & 836.7 & 790.1 \\
Non-irrigated Areas & 1443.2 & 1506 & 1575 & 1689 & 1631.1 & 1662.1 & 703.5 & 1285.4 & 1412.3 \\
Total & 2408 & 2437 & 2609.4 & 2739.5 & 2665.9 & 2727.4 & 1894.2 & 2122.4 & 2202.4 \\
\hline
\end{tabular}

Source: Department of Statistics (2021).

Table 2. Agricultural production development in Jordan from 2011 to 2019 per thousand tons

\begin{tabular}{llllllllll}
\hline Item & 2011 & 2012 & 2013 & 2014 & 2015 & 2016 & 2017 & 2018 & 2019 \\
\hline Field Crops & 188 & 243.2 & 354.4 & 382.1 & 349 & 453.1 & 205.9 & 191.4 & 234.7 \\
Fruit Trees & 426.5 & 455.1 & 436.3 & 454.2 & 621.2 & 575.7 & 532.7 & 516.2 & 603.2 \\
Vegetables & 1928.3 & 1707.7 & 1845.2 & 1930.1 & 2047.4 & 2318.3 & 1737.1 & 1824.2 & 1473 \\
Total & $2,542.80$ & $2,406.00$ & $2,635.90$ & $2,766.40$ & $3,017.60$ & $3,347.10$ & $2,475.70$ & $2,531.80$ & $2,310.90$ \\
\hline
\end{tabular}

Source: Department of Statistics (2021). 


\section{Methodology}

According to Tables 1 and 2, the agricultural areas was increased during the period 2011 to 2019 with a stable increase in agricultural production, and the total quantity of irrigation water was decreased, the agricultural sector in Jordan affected by climate change; this study will discuss and explain the effect of agricultural policy on agricultural production development under the climate change effect. A study was conducted using of Triple Likert Scale Questionnaire, targeted farmers, local community, agricultural sector decision-makers, and agricultural researchers, the questionnaire was distributed to 100 samples to study the effect of agricultural policies in responding to climate change effect on agricultural production. Representative results from the questionnaire are reported. A completely randomized design (CRD) was used in this study and calculating the means. Analysis of variance (ANOVA) was performed using the SPSS systems computer package. Treatment means were compared by the least significant difference test at $\mathrm{P}=0.05$.

\section{Results and Discussion}

The Study results depended on the questionnaire analysis, direct meeting, and notes of the targeted groups, the study tries to evaluate the opinion of target groups in five topics and discuss their results as follow:

\subsection{The Impact of Climate Change on the Agricultural Sector}

Results show that the climate change had an impact on the agricultural sector in Jordan. Table 3 indicates a significant difference which leads to the facts that the climate change could change the agricultural map. There are unusual crops cultivated in areas not used to grow and other areas start new agricultural production, the same results was found by Folnovic (2014). Global agriculture map affected by climate changes and also the same result was recorded by Kim (2016). The change in the main areas of production might be as a crisis for certain areas but might be an opportunity for other areas. However, results show agreement that there are an effect of the climate change on increasing of desertification which World Meteorological Organization reported in 2016, and the targeted group are aware of the effect of increasing water requirements for agricultural crops by the effect of climate change which show a significant differences among the samples, meanwhile, results emphasis that there are an effect of climate change on the planting of marginal areas which was also recorded by Sudmeyer et al. (2016), on the other hand, the study found that, there is an effect of climate change on the natural disasters occurred in Jordan such as flood and fires which was also founded by Maarten (2016). Table 2 shows the awareness of Jordanian people about the effect of climate change in Jordan, and there is a need to adapt the agricultural sector to reduce the effect of climate change on Jordan.

Table 3. The Impact of climate change on the agricultural sector in Jordan

\begin{tabular}{|c|c|c|c|c|c|c|c|c|c|c|c|c|c|c|}
\hline \multirow{2}{*}{ Question } & \multicolumn{3}{|c|}{ Farmers } & \multicolumn{3}{|c|}{$\begin{array}{l}\text { Agricultural Rural } \\
\text { Community }\end{array}$} & \multicolumn{3}{|c|}{$\begin{array}{l}\text { Agricultural Sector } \\
\text { Decision-Makers }\end{array}$} & \multicolumn{3}{|c|}{ Agricultural Researchers } & \multirow{2}{*}{ Sig. } & \multirow{2}{*}{ LSD } \\
\hline & $\begin{array}{l}\text { Not } \\
\text { Agree }\end{array}$ & Neutral & Agree & $\begin{array}{l}\text { Not } \\
\text { Agree }\end{array}$ & Neutral & Agree & $\begin{array}{l}\text { Not } \\
\text { Agree }\end{array}$ & Neutral & Agree & $\begin{array}{l}\text { Not } \\
\text { Agree }\end{array}$ & Neutral & Agree & & \\
\hline Change the agricultural map & 0 & 5 & 20 & 2 & 3 & 20 & 0 & 0 & 25 & 0 & 0 & 25 & $*$ & 0.211 \\
\hline $\begin{array}{l}\text { Increasing rates of desertification } \\
\text { of agricultural lands }\end{array}$ & 0 & 7 & 18 & 0 & 1 & 24 & 0 & 0 & 25 & 0 & 0 & 25 & $*$ & 0.182 \\
\hline $\begin{array}{l}\text { Increasing water requirements } \\
\text { for agricultural crops }\end{array}$ & 0 & 3 & 22 & 1 & 4 & 20 & 0 & 0 & 25 & 0 & 0 & 25 & $*$ & 0.133 \\
\hline $\begin{array}{l}\text { Impact on the possibility of } \\
\text { planting marginal areas }\end{array}$ & 0 & 1 & 24 & 5 & 10 & 10 & 0 & 0 & 25 & 0 & 0 & 25 & $*$ & 0.124 \\
\hline $\begin{array}{l}\text { High incidence of natural } \\
\text { disasters such as floods, } \\
\text { early reclamations and fires }\end{array}$ & 0 & 2 & 23 & 0 & 3 & 22 & 0 & 0 & 25 & 0 & 0 & 25 & $*$ & 0.156 \\
\hline
\end{tabular}

Note. * Significant at $\mathrm{P} \leq 0.05$.

\subsection{The Impact of Climate Change on Agricultural Production}

According to Table 4, results show significant differences except for the effect of climate change on reducing the quality of agricultural production. Anyway, it's clear that there is awareness among the targeted group of the effect of climate change on agricultural production in different ways we suggested by reducing agricultural production which is compatible with the results Kim (2016), noticed that climate change not only affects the growth of fruit trees but also their quality, harvest time and storage, and its production what we discuss at the effect of climate change on reducing the quality of agricultural production too. On the other hand, results show that the agreement that climate change will affect the wild varieties which were recorded by Jarvis et al. (2008), 
the survival of some of these wild plant species could be threatened because of climate change. Nelson et al. (2009) indicated that agriculture is extremely vulnerable to climate change. Higher temperatures eventually reduce yields of desirable crops while encouraging weed and pest proliferation. If climate change instead leads to higher cost of production and reduced supply, higher prices will negatively affect consumers while making producers better off (Liu, Zilberman, \& Sunding, 2002).

Table 4. The impact of climate change on the agricultural production in Jordan

\begin{tabular}{|c|c|c|c|c|c|c|c|c|c|c|c|c|c|c|}
\hline \multirow{2}{*}{ Question } & \multicolumn{3}{|c|}{ Farmers } & \multicolumn{3}{|c|}{$\begin{array}{l}\text { Agricultural Rural } \\
\text { Community }\end{array}$} & \multicolumn{3}{|c|}{$\begin{array}{l}\text { Agricultural Sector } \\
\text { Decision-Makers }\end{array}$} & \multicolumn{3}{|c|}{ Agricultural Researchers } & \multirow{2}{*}{ Sig. } & \multirow{2}{*}{ LSD } \\
\hline & $\begin{array}{l}\text { Not } \\
\text { Agree }\end{array}$ & Neutral & Agree & $\begin{array}{l}\text { Not } \\
\text { Agree }\end{array}$ & Neutral & Agree & $\begin{array}{l}\text { Not } \\
\text { Agree }\end{array}$ & Neutral & Agree & $\begin{array}{l}\text { Not } \\
\text { Agree }\end{array}$ & Neutral & Agree & & \\
\hline Reducing agricultural production & 6 & 2 & 17 & 9 & 1 & 15 & 0 & 3 & 22 & 0 & 0 & 25 & $*$ & 0.622 \\
\hline $\begin{array}{l}\text { Increased infection with } \\
\text { insect and fungal pests } \\
\text { and various plant diseases }\end{array}$ & 0 & 7 & 18 & 7 & 3 & 15 & 0 & 0 & 25 & 0 & 0 & 25 & $*$ & 0.438 \\
\hline $\begin{array}{l}\text { The disappearance of wild } \\
\text { varieties of agricultural crops }\end{array}$ & 3 & 2 & 20 & 6 & 2 & 17 & 0 & 4 & 21 & 0 & 0 & 25 & $*$ & 0.331 \\
\hline $\begin{array}{l}\text { Increasing agricultural } \\
\text { production costs }\end{array}$ & 2 & 8 & 15 & 2 & 2 & 21 & 0 & 0 & 25 & 3 & 6 & 16 & $*$ & 0.221 \\
\hline $\begin{array}{l}\text { Poor quality of } \\
\text { agricultural products }\end{array}$ & 0 & 12 & 13 & 1 & 2 & 22 & 0 & 4 & 21 & 11 & 4 & 10 & $\mathrm{~ns}$ & - \\
\hline
\end{tabular}

Note. * Significant at $\mathrm{P} \leq 0.05$.

\subsection{The Impact of Agricultural Policies on the Agricultural Sector}

The results in Table 5 shows that the targeted group was agreed that the agricultural policy is a must to develop the agricultural sector in Jordan, the agricultural policies implementation will increase agricultural land, increase agricultural investments, facilitate national and international trade through different regulations and agreements, and it will develop the agricultural sector by providing different services, this was also mentioned by the Organization for Economic Co-operation and Development (OECD) (2013), the agricultural policies might impact agricultural productivity growth, sustainable use of natural assets such as land, water, and biodiversity resources, and climate change. The same results were indicated by Daci (2016), were the agricultural policy in Kosovo within the period of 1999-2015 development of agriculture sector by increasing the agricultural land, agricultural investment and solving of problems facing the agricultural sector.

Table 5. The impact of agricultural policies on the agricultural sector in Jordan

\begin{tabular}{|c|c|c|c|c|c|c|c|c|c|c|c|c|c|c|}
\hline \multirow{2}{*}{ Question } & \multicolumn{3}{|c|}{ Farmers } & \multicolumn{3}{|c|}{$\begin{array}{l}\text { Agricultural Rural } \\
\text { Community }\end{array}$} & \multicolumn{3}{|c|}{$\begin{array}{l}\text { Agricultural Sector } \\
\text { Decision-Makers }\end{array}$} & \multicolumn{3}{|c|}{ Agricultural Researchers } & \multirow{2}{*}{ Sig. } & \multirow{2}{*}{ LSD } \\
\hline & $\begin{array}{l}\text { Not } \\
\text { Agree }\end{array}$ & Neutral & Agree & $\begin{array}{l}\text { Not } \\
\text { Agree }\end{array}$ & Neutral & Agree & $\begin{array}{l}\text { Not } \\
\text { Agree }\end{array}$ & Neutral & Agree & $\begin{array}{l}\text { Not } \\
\text { Agree }\end{array}$ & Neutral & Agree & & \\
\hline Increasing agricultural areas & 3 & 9 & 13 & 11 & 6 & 7 & 2 & 0 & 23 & 1 & 3 & 21 & $*$ & 0.357 \\
\hline $\begin{array}{l}\text { Solve the problems facing } \\
\text { the agricultural sector }\end{array}$ & 12 & 6 & 7 & 5 & 3 & 17 & 0 & 0 & 25 & 2 & 1 & 22 & ns & - \\
\hline $\begin{array}{l}\text { Facilitating investment } \\
\text { operations in the } \\
\text { agricultural sector }\end{array}$ & 4 & 10 & 11 & 5 & 1 & 19 & 6 & 0 & 19 & 1 & 2 & 22 & $*$ & 0.159 \\
\hline $\begin{array}{l}\text { Facilitating agricultural } \\
\text { foreign trade operations }\end{array}$ & 0 & 12 & 13 & 0 & 4 & 21 & 0 & 0 & 25 & 1 & 1 & 23 & $*$ & 0.147 \\
\hline $\begin{array}{l}\text { Providing services to } \\
\text { the agricultural sector }\end{array}$ & 4 & 3 & 18 & 0 & 0 & 25 & 0 & 0 & 25 & 1 & 0 & 24 & $*$ & 0.258 \\
\hline
\end{tabular}

Note. * Significant at $\mathrm{P} \leq 0.05$.

\subsection{The Impact of Agricultural Policies on Agricultural Production}

The agricultural sector in Jordan is characterized by a comparative advantage, which is early production, especially in the Jordan Valley areas. Therefore, agricultural policies supported agricultural production processes to enhance the Kingdom's food security and increase farmers' income. The study addressed the most important thing that Jordanian agricultural policies do to support agricultural production. According to the Table 6, there are significant differences that the agricultural policies enhance agricultural production through providing the 
agricultural needs for products with low prices, facilitate the trade of agricultural commodities and rise the quality of agricultural products through applying different systems such as global good agricultural Practices certificate and develop of local agricultural practices certificate, organic production certificate to facilitate agricultural trade and to produce healthy agricultural products. The results show that no significance to the support agricultural policy to the providing of new technology in agricultural production. Meanwhile, the agricultural policies try to connect farmers with research centers to transfer new technology to the agricultural sector. DeBoe (2020) reported that the agricultural policies stimulate both agricultural productivity growth and environmental sustainability, while also determining whether there would be synergies or trade-offs between productivity and sustainability objectives.

Table 6. The impact of agricultural policies on the agricultural production in Jordan

\begin{tabular}{|c|c|c|c|c|c|c|c|c|c|c|c|c|c|c|}
\hline \multirow{2}{*}{ Question } & \multicolumn{3}{|c|}{ Farmers } & \multicolumn{3}{|c|}{$\begin{array}{l}\text { Agricultural Rural } \\
\text { Community }\end{array}$} & \multicolumn{3}{|c|}{$\begin{array}{l}\text { Agricultural Sector } \\
\text { Decision-Makers }\end{array}$} & \multicolumn{3}{|c|}{ Agricultural Researchers } & \multirow{2}{*}{ Sig. } & \multirow{2}{*}{ LSD } \\
\hline & $\begin{array}{l}\text { Not } \\
\text { Agree }\end{array}$ & Neutral & Agree & $\begin{array}{l}\text { Not } \\
\text { Agree }\end{array}$ & Neutral & Agree & $\begin{array}{l}\text { Not } \\
\text { Agree }\end{array}$ & Neutral & Agree & $\begin{array}{l}\text { Not } \\
\text { Agree }\end{array}$ & Neutral & Agree & & \\
\hline $\begin{array}{l}\text { Providing the requirements } \\
\text { of agricultural production }\end{array}$ & 2 & 12 & 11 & 1 & 9 & 15 & 0 & 0 & 25 & 0 & 9 & 16 & $*$ & 0.146 \\
\hline $\begin{array}{l}\text { Providing modern technologies } \\
\text { for agricultural production }\end{array}$ & 11 & 7 & 7 & 9 & 4 & 17 & 4 & 6 & 15 & 11 & 8 & 6 & ns & - \\
\hline $\begin{array}{l}\text { Facilitating the export } \\
\text { of agricultural products }\end{array}$ & 6 & 1 & 18 & 4 & 0 & 21 & 0 & 0 & 25 & 0 & 0 & 25 & $*$ & 0.189 \\
\hline $\begin{array}{l}\text { Organizing agricultural } \\
\text { production operations }\end{array}$ & 15 & 3 & 7 & 11 & 1 & 13 & 0 & 2 & 23 & 0 & 0 & 25 & $*$ & 0.231 \\
\hline $\begin{array}{l}\text { Raise the quality of } \\
\text { agricultural products }\end{array}$ & 7 & 12 & 6 & 6 & 4 & 15 & 0 & 0 & 25 & 6 & 0 & 19 & $*$ & 0.253 \\
\hline
\end{tabular}

Note. * Significant at $\mathrm{P} \leq 0.05$.

\subsection{The Effect of Agricultural Policies in Limiting the Effects of Climate Change on Agricultural Production}

Climate change and agriculture are interrelated processes, both of which take place on a global scale, with the adverse effects of climate change affecting agriculture both directly and indirectly. A range of policies can reduce the risk of negative climate change impacts on agriculture and greenhouse gas emissions from agriculture (Porter et al., 2014). Table 7 indicated a significant effect of agricultural policies in limiting the effect of climate change, it became clear that the agricultural policies were effective in facing climate change in different ways, by enhancing agricultural production, providing modern technologies, organizing agricultural production operations, improve the quality of agricultural products, increasing agricultural land, solving the problems facing the agricultural sector, providing of agricultural services, enhancing agricultural trade system, and facilitating investment. 
Table 7. The effect of agricultural policies in limiting the effects of climate change on agricultural production in Jordan

\begin{tabular}{|c|c|c|c|c|c|c|c|c|c|c|c|c|c|c|}
\hline \multirow{2}{*}{ Question } & \multicolumn{3}{|c|}{ Farmers } & \multicolumn{3}{|c|}{$\begin{array}{l}\text { Agricultural Rural } \\
\text { Community }\end{array}$} & \multicolumn{3}{|c|}{$\begin{array}{l}\text { Agricultural Sector } \\
\text { Decision-Makers }\end{array}$} & \multicolumn{3}{|c|}{$\begin{array}{l}\text { Agricultural } \\
\text { Researchers }\end{array}$} & \multirow{2}{*}{ Sig. } & \multirow{2}{*}{ LSD } \\
\hline & $\begin{array}{l}\text { Not } \\
\text { Agree }\end{array}$ & Neutral & Agree & $\begin{array}{l}\text { Not } \\
\text { Agree }\end{array}$ & Neutral & Agree & $\begin{array}{l}\text { Not } \\
\text { Agree }\end{array}$ & Neutral & Agree & $\begin{array}{l}\text { Not } \\
\text { Agree }\end{array}$ & Neutral & Agree & & \\
\hline $\begin{array}{l}\text { Agricultural policies in Jordan } \\
\text { are ineffective in limiting the } \\
\text { effects of climate change on } \\
\text { agricultural production }\end{array}$ & 12 & 2 & 11 & 16 & 3 & 6 & 22 & 3 & 0 & 19 & 4 & 2 & $*$ & 0.113 \\
\hline $\begin{array}{l}\text { Agricultural policies in Jordan } \\
\text { are working to reduce the } \\
\text { effects of climate change on } \\
\text { agricultural production }\end{array}$ & 0 & 3 & 22 & 0 & 2 & 23 & 0 & 1 & 24 & 0 & 2 & 23 & $*$ & 0.365 \\
\hline $\begin{array}{l}\text { Agricultural policies are very } \\
\text { important for agricultural } \\
\text { production in Jordan in the } \\
\text { climate change conditions } \\
\text { facing the Kingdom }\end{array}$ & 3 & 0 & 22 & 1 & 2 & 22 & 0 & 1 & 24 & 0 & 0 & 25 & $*$ & 0.421 \\
\hline $\begin{array}{l}\text { Agricultural policies in Jordan } \\
\text { are resisting climate change } \\
\text { affecting agricultural production }\end{array}$ & 0 & 0 & 25 & 1 & 0 & 24 & 0 & 1 & 24 & 2 & 3 & 20 & $*$ & 0.312 \\
\hline $\begin{array}{l}\text { Agricultural policies support } \\
\text { the continuity of agricultural } \\
\text { production in Jordan in } \\
\text { conditions of climatic changes } \\
\text { facing the Kingdom }\end{array}$ & 0 & 0 & 25 & 1 & 0 & 24 & 0 & 1 & 24 & 1 & 1 & 23 & $*$ & 0.222 \\
\hline
\end{tabular}

Note. * Significant at $\mathrm{P} \leq 0.05$.

\section{Conclusions}

The climatic change could affect agriculture in several ways: Crop productivity in terms of quantity and quality, agricultural Practices, through changes of water use (irrigation) and agricultural inputs such as fertilizers and pesticides, environmental effects, in particular concerning frequency and intensity of soil drainage, soil erosion and reduction of crop diversity and land use through the loss and gain of cultivated lands, land speculation, land, and hydraulic amenities. The study found that the agricultural policies in Jordan and the Jordanian community was aware of the effect of climate change on the agricultural sector which reflects on the agricultural production, many regulations were set up to organize the agricultural sector in Jordan that became a defender for the Jordanian agricultural food production in Jordan, the effective agricultural policies in Jordan was one of the elements must be developed as a challenge to face the climatic changes in Jordan.

\section{References}

Al-Bitar, L. (2008). Organic Farming in the Mediterranean: Towards Further Development (CIHEAM Analytical Notes No. 30). Mediterranean Agronomic Institute of Bari (CIHEAM-IAMB).

Bany Yasin, H. (2018). The Case of the Hashemite Kingdom of Jordan. In A. C. T. Alliance (Ed.), Enhanced Climate Action in Response to $1.5^{\circ} \mathrm{C}$ of Global Warming. Scaling up Nationally Determined Contributions (pp. 53-63). Retrieved from https://www.preventionweb.net/files/62199_actalliancereport1.5c.pdf

Combaz, E. (2019). Jordan's environmental policies and engagement on climate change (K4D Helpdesk Report). Brighton, UK: Institute of Development Studies.

Daci, E. (2016). Impact of Agricultural Policy in Development of Agriculture Sector within the Period of 1999-2015 in Kosovo. European Journal of Multidisciplinary Studies, 1(4), 10-16. https://doi.org/ 10.26417/ejms.v1i4.p10-16

DeBoe, G. (2020). Impacts of agricultural policies on productivity and sustainability performance in agriculture: A literature review. OECD Food, Agriculture and Fisheries Papers (No. 141). OECD Publishing, Paris. https://doi.org/10.1787/6bc916e7-en

DOS (Jordan Department of Statistics). (2021). Statistical Yearbook of Jordan (Annual Report 2019).

EcoPeace (EcoPeace Middle East). (2019). Climate Change, Water Security, and National Security for Jordan. Palestine: EcoPeace Middle East; Israel: Konrad Adenauer Stiftung. Retrieved from http://ecopeaceme.org/ wp-content/uploads/2019/01/climatechange-web.pdf? 
Folnovic, T. (2014). Global Agriculture Map Affected by Climate Changes. Retrieved from https://blog.agrivi.com/post/global-agriculture-map-affected-by-climate-changes

Freiwan, M. (2008). Climate, climatic trends and climate change scenarios vulnerability \& adaptation to climate change. Dissemination Workshop, Enabling Activities for the Preparation of Jordan's Second National Communication to the UNFCCC.

Freiwan, M., \& Kadioglub, M. (2008). Spatial and temporal analysis of climatological data in Jordan. Int. J. Climatol., 28, 521-535. https://doi.org/10.1002/joc.1562

IPCC (Intergovernmental Panel on Climate Change). (2007). Contribution of Working Group II to the Fourth Assessment Report of the Intergovernmental Panel on Climate Change. In M. L. Parry, O. F. Canziani, J. P. Palutikof, P. J. van der Linden, \& C. E. Hanson (Eds.), Climate Change 2007: Impacts, Adaptation and Vulnerability (p. 976). Cambridge University Press, Cambridge, UK.

Jarvis, A., Lane, A., \& Hijmans, R. (2008). The effect of climate change on crop wild relatives. Agriculture Ecosystems \& Environment, 126(1-2), 13-23. https://doi.org/10.1016/j.agee.2008.01.013

Kim, C. G. (2016). The Impact of Climate Change on the Agricultural Sector: Implications of the Agro-Industry for Low Carbon, Green Growth Strategy and Road Map for the East Asia Region. Korea Rural Economic Institute.

Liu, X., Zilberman, D., \& Sunding, D. (2002). The Impact of Climate Change on Agriculture: A Conceptual Study. Working Paper, Department of Agricultural and Resource Economics, University of California, Berkeley. https://doi.org/10.1007/978-1-4615-1543-2_20

Maarten, K. V. A. (2016). The Impact of Climate Change on the Risk of Natural Disasters. Red Cross/Red Crescent on Climate Change and Disaster Preparedness, Netherlands.

MoEnv (Jordan Ministry of Environment). (2013). The National Climate Change Policy of the Hashemite Kingdom of Jordan 2013-2020.

Moshrik, R., Abu-Allaban, M., Al-Shayeb, A., Jaber, M., \& Momani, N. (2009). Climate Change in Jordan: A Comprehensive Examination Approach. American Journal of Environmental Sciences, 5(1), 58-68. https://doi.org/10.3844/ajessp.2009.58.68

Namrouqa, H. (2009). Jordan to carry out Studies for new projects to cut greenhouse gas emissions. Arab Environment Watch. Retrieved from http://www.arabenvironment.net/archive/2009/12/990813.html

Nelson, G. C., Rosegrant, M. W., Koo, J., \& Robertson, R. (2009). Climate Change: Impact on Agriculture and Costs of Adaptation. International Food Policy Research Institute.

OECD (Organization for Economic Co-operation and Development). (2013). Agricultural Innovation Systems: A Framework for Analyzing the Role of the Government. OECD Publishing, Paris. https://doi.org/ 10.1787/9789264200593-en

Porter, J. R., Xie, L., Challinor, A. J., Cochrane, K., Howden, S. M., Iqbal, M. M., Lobell, D. B., Travasso, M. I. (2014). Section 7.5: Adaptation and Managing Risks in Agriculture and Other Food System Activities. Food security and food production systems (Chapter 7, pp. 513-520). Contribution of Working Group II to the Fifth Assessment Report of the Intergovernmental Panel on Climate Change, Cambridge University Press.

Sudmeyer, R. A., Edeard, A., Fazakerley, V., Simpkin, L., \& Foster, I. (2016). Climate Change: Impacts and Adaptation for Agriculture in Western Australia. Department of Primary Industries and Regional Development, Australia.

Taimeh, A. (2010). Rethinking Agricultural Development of Dry Lands: Challenges of Climate Change. International Conference on Food Security and Climate Change in Dry Areas, February 1-4, 2010. University of Jordan Amman, Jordan.

UNFCCC (United Nations Framework Convention on Climate Change). (2009). Jordan's Second National Communication to the United Nations Framework Convention on Climate Change (UNFCCC) (Deposit No.: 2009/11/4731). Jordan Ministry of Environment, Amman.

Wardam, B. (2009). Jordan and Climate Change. Jordan Watch. Retrieved from http://www.jordanwatch.net/ archive/2009/5/883737.html 


\section{Copyrights}

Copyright for this article is retained by the author(s), with first publication rights granted to the journal.

This is an open-access article distributed under the terms and conditions of the Creative Commons Attribution license (http://creativecommons.org/licenses/by/4.0/). 